\title{
IMPROVING TEACHERS' ABILITY IN IMPLEMENTING PAKEM THROUGH MGMP AT SMA NEGERI 1 TASIFETO BARAT, NUSA TENGGARA TIMUR
}

\author{
Ulu Emanuel \\ Universitas Timor, Kefamenanu, Timor, NTT, Indonesia \\ emanuelululuis@gmail.com
}

\begin{abstract}
This study aimed to determine whether the supervision activities by supervisors in Subject Teacher Organization (or MGMP) could improve teachers abilities to implement the active, creative, effective, and fun learning (or PAKEM). To obtain the data needed, this study involved 34 teachers of SMA Negeri 1 Tasifeto Barat and was carried out in three months, starting from 18 August 2019 to 13 October 2019. The results of this study indicated that the teachers' ability to prepare PAKEM model increased after coaching was carried out by supervisors in the MGMP. The increase was proved by an increase in the average percentage of lesson plan (RPP) preparation, that was $61.19 \%$ in cycle I and $67.77 \%$ in cycle II as well as the teachers' ability to compile learning scenarios and components in designing classroom management by determining the types of learning activities that provided opportunities to involve students with detailed and challenging steps for improvement. Therefore, it was suggested that supervisors and school principals took the advantage of the school MGMP forum as a target for teacher training to improve their quality of learning activities and teachers could actively participate in MGMP activities, as one of the forums for improving their quality.
\end{abstract}

Keywords: PAKEM, via MGMP

\section{MENINGKATKAN KEMAMPUAN GURU DALAM MELAKSANAKAN PAKEM MELALUI MGMP DI SMA NEGERI 1 TASIFETO BARAT, NUSA TENGGARA TIMUR}

\section{ABSTRAK}

Penelitian ini bertujuan untuk mengetahui apakah kegiatan pembinaan pengawas di MGMP sekolah dapat meningkatkan kemampuan guru dalam melaksanakan pembelajaran PAKEM. Untuk memperoleh data, peneliti melibatkan 34 guru di SMA Negeri 1 Tasifeto Barat dan dilakukan pada selama tiga bulan yaitu mulai tanggal 18 Agustus 2019 sampai dengan 13 Oktober 2019. Hasil penelitian ini menunjukkan bahwa kemampuan guru dalam menyusun Rencana Pelaksanaan Pembelajaran menggunakan model PAKEM meningkat setelah dilakukan pembinaan oleh pengawas di MGMP sekolah. Peningkatan kemampuan guru ini ditandai dengan kenaikan rata-rata persentase penyusunan RPP sebesar 61.19\% pada siklus I dan 67.77\% pada siklus II dan kemampuan guru dalam menyusun skenario pembelajaran dan komponen merancang pengelolaan kelas dengan menentukan jenis kegiatan pembelajaran yang memberi peluang melibatkan siswa dengan langkah-langkah yang rinci dan menantang untuk peningkatan. Karena itu, disarankan agar pengawas dan kepala sekolah dalam melaksanakan kerjanya dapat memanfaatkan forum MGMP sekolah sebagai sasaran pembinaan guru untuk meningkatkan kualitas kegiatan pembelajaran dan guru dapat aktif mengikuti kegiatan MGMP, sebagai salah satu forum peningkatan kualitasnya.

Kata Kunci: PAKEM, melalui MGMP

\begin{tabular}{|c|c|c|}
\hline Submitted & Accepted & Published \\
\hline 31 Agustus 2020 & 05 September 2021 & 16 September 2021 \\
\hline
\end{tabular}

\begin{tabular}{|l|c|c|c|}
\hline Citation & $:$ & $\begin{array}{r}\text { Emanuel, U. (2021). Improving Teachers' Ability in Implementing PAKEM through MGMP at SMA Negeri 1 Tasifeto } \\
\text { Barat, Nusa Tenggara Timu. Jurnal PAJAR (Pendidikan dan Pengajaran), 5(5), 1339-1352. DOI : } \\
\text { http://dx.doi.org/10.33578/pjr.v5i5.8130. }\end{array}$ \\
\hline
\end{tabular}

\section{PENDAHULUAN}

Pembelajaran aktif, kreatif, efektif dan menyenangkan (PAKEM) merupakan sebuah model pembelajaran kontektual yang melibatkan paling sedikit empat prinsip utama dalam proses pembelajarannya. Pertama, proses interaksi (siswa berinteraksi secara aktif dengan guru, rekan siswa, multi media, referensi, lingkungan, dsb). Kedua, proses komunikasi (siswa mengkomunikasikan pengalaman belajar mereka dengan guru dan rekan siswa lain melalui cerita, dialog atau melalui simulasi role-play). Ketiga, proses refleksi (siswa memikirkan kembali tentang kebernaknaan apa 
yang merka telah pelajari, dan apa yang telah mereka lakukan). Dan keempat, proses eksplorasi (siswa mengalami langsung dengan melibatkan semua indra mereka melalui pengamatan, percobaan, penyelidikan dan atau wawancara).

Sesuai dengan tuntutan kurikulum, pembelajaran dalam kurikulum berbasis kompetensi ditekankan pada pencapaian kompetensi pada ketiga ranah yaitu kognitif, afektif dan psikomotor. Untuk itu guru perlu memilih pendekatan pembelajaran yang sesuai dengan tuntutan kurikulum yaitu PAKEM.

Sebagai pengawas yang telah melaksanakan supervisi akademik melalui kegiatan supervisi kunjungan kelas, penulis menemukan bahwa pada umumnya guru belum menggunakan pendekatan pembelajaran yang sesuai dengan tuntutan kurikulum yang mengarahkan siswa pada pencapaian ketiga ranah dan yang bisa menjadikan proses pembelajaran efektif dan menyenangkan. Sebagian besar guru yang disupervisi masih melaksanakan pembelajaran konvensional dengan metode ceramah.

Penggunaan metode yang konvensional itu kurang dapat mengembangkan kemampuankemampuan siswa seperti yang dituntut oleh kurikulum berbasis kompetensi seperti kemampuan bekerjasama, kemampuan memecahkan masalah, dan sebagainya. Oleh karena itu sebagai pengawas merasa perlu untuk melakukan perbaikan kegiatan belajar mengajar di sekolah yang menjadi binaan penulis melalui penelitian tindakan sekolah.

Berdasarkan penjelasan kepala sekolah dan wawancara dengan guru terungkap bahwa selama ini konsep pendekatan PAKEM, belum dilaksanakan oleh guru. Selain itu, bagi guru yang sudah memahami konsep model pembelajaran ini, masih sulit menyusun rencana pembelajaran. Untuk itu, pembinaan terhadap guru dalam meningkatkan kemampuannya untuk melaksanakan PAKEM perlu dilakukan pengawasan terhadap Musyawarah Guru Mata Pelajaran (MGMP) sekolah. Forum MGMP sekolah telah ada di setiap sekolah namun pelaksanaannya kurang efektif mendorong para guru untuk menerapkan pendekatan PAKEM dalam pembelajarannya.

\section{KAJIAN TEORETIS}

\section{Konsep PAKEM}

Guru adalah tenaga pendidik pada jenjang pendidikan dasar dan menengah yang bertugas melaksanakan proses pembelajaran yang mempunyai lima tugas pokok yaitu: (a) menyusun perencanaan kegiatan belajar mengajar, (b) melaksanakan kegiatan belajar mengajar, (c) melaksanakan evaluasi belajar mengajar, (d) melaksanakan analisis hasil evaluasi, dan (e) melaksanakan tindak lanjut hasil evaluasi. Kelima tugas pokok di atas ingin mempertegas pembelajaran sebagai suatu kombinasi yang tersusun dari unsur manusiawi, material, fasilitas, perlengkapan dan prosedur yang saling mempengaruhi untuk mencapai tujuan pembelajaran.

Dalam melaksanakan pembelajaran, seorang guru mau tidak mau harus berperan aktif, proaktif, dan kreaktif untuk mencari dan merancang media/bahan ajar alternatif yang mudah dan sederhana, tetapi tetap memiliki relevansi dengan tema mata pelajaran yang sedang dipelajari siswa. Aktif menghendaki agar guru harus menciptakan suasana pembelajaran bertanya, mempertanyakan, dan mengemukakan gagasan dari pihak siswa. Peran aktif siswa sangat penting dalam rangka pembentukan generasi yang kreatif. Kreatif dimaksudkan agar guru menciptakan kegiatan belajar yang beragam sehingga memenuhi berbagai tingkat kemampuan siswa. Menyenangkan adalah suasana belajarmengajar yang mendorong siswa untuk secara efektif memusatkan perhatiannya secara penuh pada pembelajaran.

Secara garis besar, gambaran PAKEM adalah sebagai berikut: (a) siswa terlibat dalam berbagai kegiatan yang mengembangkan pemahaman dan kemampuan mereka dengan penekanan pada belajar melalui berbuat, (b) guru menggunakan berbagai alat bantu dan cara membangkitkan semangat, termasuk menggunakan lingkungan sebagai sumber belajar untuk menjadikan pembelajaran menarik, menyenangkan, dan cocok bagi siswa, (c) guru 
mengatur kelas dengan memajang buku-buku dan bahan belajar yang lebih menarik dan menyediakan 'pojok baca', (d) guru menerapkan cara mengajar yang lebih kooperatif dan interaktif, termasuk cara belajar kelompok, dan (e) guru mendorong siswa untuk menemukan caranya sendiri dalam pemecahan suatu masalah, untuk mengungkapkan gagasannya, dan melibatkam siswa dalam menciptakan lingkungan sekolahnya. Dari beberapa studi terdahulu tentang penggunaan Model PAKEM dalam pembelajaran telah mengungkapkan efektivitasnya. Misalnya, Dede Rohaniawati (2016), I Iesti Surya Ningsih, dan Yudi Darma, dan Yadi Ardiawan (2018) menemukan bahwa pembelajaran siswa dengan menggunakan pendekatan atau model PAKEM dapat meningkatkan interaksi dan komunikasi antara guru dan siswa. Hal yang sama juga diakui oleh S. A. Suharman, Pariabti Palloan dan Eko Hadi Sujiono (2011). Dengan penggunakan rumus persentase dan " $r$ " Product Moment dan pengujian statistik inferensial, mereka menemukan korelasi dan pengaruh penggunaan PAKEM dalam pembelajaran siswa.

\section{Pembinaan Pengawas Sekolah}

Tugas pokok pengawas sekolah/satuan pendidikan adalah melakukan penilaian dan pembinaan dengan melaksanakan fungsi-fungsi supervisi, baik supervisi akademik maupun supervisi manajerial. Berdasarkan tugas pokok dan fungsi di atas minimal ada tiga kegiatan yang harus dilaksanakan pengawas yakni: (a) melakukan pembinaan pengembangan kualitas sekolah, kinerja kepala sekolah, kinerja guru, dan kinerja seluruh staf sekolah, (b) melakukan evaluasi dan monitoring pelaksanaan program sekolah beserta pengembangannya, dan (c) melakukan penilaian terhadap proses dan hasil program pengembangan sekolah secara kolaboratif dengan stakeholder sekolah.

Mengacu pada SK Menpan nomor 118 tahun 1996 tentang jabatan fungsional pengawas dan angka kreditnya, Keputusan bersama Mendikbud Nomor 03420/O/1996 dan Kepala Badan Administrasi Kepegawaian Negara Nomor 38 tahun 1996 tentang petunjuk pelaksanaan jabatan fungsional pengawas serta Keputusan
Mendikbud Nomor 020/U/1998 tentang petunjuk teknis pelaksanaan jabatan fungsional pengawas sekolah dan angka kreditnya, dapat dikemukakan tentang tugas pokok dan tanggung jawab pengawas sekolah yang meliputi: (a) melaksanakan pengawasan penyelenggaraan pendidikan di sekolah sesuai dengan penugasannya pada TK, SD, SLB, SLTP dan SLTA, dan (b) meningkatkan kualitas proses belajar-mengajar/bimbingan dan hasil prestasi belajar/bimbingan siswa dalam rangka mencapai tujuan pendidikan.

Tugas pokok yang pertama merujuk pada supervisi atau pengawasan manajerial sedangkan tugas pokok yang kedua merujuk pada supervisi atau pengawasan akademik. Pengawasan manajerial pada dasarnya memberikan pembinaan, penilaian dan bantuan/bimbingan mulai dari rencana program, proses, sampai dengan hasil. Bimbingan dan bantuan diberikan kepada kepala sekolah dan seluruh staf sekolah dalam pengelolaan sekolah atau penyelenggaraan pendidikan di sekolah untuk meningkatkan kinerja sekolah. Pengawasan akademik berkaitan dengan membina dan membantu guru dalam meningkatkan kualitas proses pembelajaran/bimbingan dan kualitas hasil belajar siswa.

Sedangkan wewenang yang diberikan kepada pengawas sekolah meliputi: (1) memilih dan menentukan metode kerja untuk mencapai hasil yang optimal dalam melaksanakan tugas dengan sebaik-baiknya sesuai dengan kode etik profesi, (2) menetapkan tingkat kinerja guru dan tenaga lainnya yang diawasi beserta faktor-faktor yang mempengaruhinya, (3) menentukan atau mengusulkan program pembinaan serta melakukan pembinaan.

Berdasarkan kedua tugas pokok di atas, Sudrajat, A. (2008) menjelaskan bahwa kegiatan yang dilakukan oleh pengawas antara lain: (a) menyusun program kerja kepengawasan untuk setiap semester dan setiap tahunnya pada sekolah yang dibinanya, (b) melaksanakan analisis komprehensif berbagai faktor sumber daya pendidikan sebagai bahan untuk melakukan inovasi sekolah, (c) melaksanakan penilaian dan monitoring penyelenggaran pendidikan di sekolah 
binaannya mulai dari penerimaan siswa baru, pelaksanaan pembelajaran, pelaksanaan ujian sampai kepada pelepasan lulusan/pemberian ijazah, dan (d) memberikan saran dan pertimbangan kepada pihak sekolah dalam memecahkan masalah yang dihadapi sekolah berkaitan dengan penyelenggaraan pendidikan.

Atas dasar uraian di atas, Sudrajat, A. (2008) menambahkan bahwa tugas pengawas mencakup: (1) inspecting (mensupervisi), (2) advising (memberi advis atau nasehat), (3) monitoring (memantau), (4) reporting (membuat laporan), (5) coordinating (mengkoordinir) dan (6) performing leadership dalam arti memimpin dalam melaksanakan kelima tugas pokok tersebut. Sedangkan pengawas satuan pendidikan berperan sebagai: (1) penilai, (2) peneliti, (3) pengembang, (4) pelopor/inovator, (5) motivator, (6) konsultan, dan (7) kolaborator dalam rangka meningkatkan mutu pendidikan di sekolah binaannya.

\section{Musyawarah Guru Mata Pelajaran (MGMP)}

MGMP merupakan forum pembinaan guru melalui teman sejawat dan dilaksanakan mulai dari tingkat sekolah, kecamatan, kabupaten dan di tingkat provinsi. Dalam MGMP, guru-guru yang mengajar mata pelajaran sejenis melakukan pertemuan secara periodik untuk berdiskusi, membahas berbagai hal yang berhubungan dengan tugas guru seperti: menyusun silabus dan rencana pelaksanaan pembelajaran, pendalaman materi, penyiapan bahan ajar, pemilihan pendekatan dan metode mengajar, menyusun alat evaluasi dan melaksanakan analisis hasil evaluasi untuk penyusunan program tindak lanjut.

Pada hakikatnya kegiatan MGMP adalah kegiatan yang dilakukan oleh guru, dari guru dan untuk guru. Namun demikian tidak menutup kemungkinan dalam setiap kegiatan mendatangkan nara sumber dari luar MGMP, misalnya kepala sekolah, pengawas maupun dosen dari perguruan tinggi atau widya iswara dari LPMP jika diperlukan.

Menurut Ahcmad (2004), tujuan diselenggarakannya MGMP ialah (1) memotivasi guru guna meningkatkan kemampuan dan keterampilan dalam merencanakan, melaksanakan, dan membuat evaluasi program pembelajaran dalam rangka meningkatkan keyakinan diri sebagai guru profesional, (2) menyatakan kemampuan dan kemahiran guru dalam melaksanakan pembelajaran sehingga dapat menunjang usaha peningkatan dan pemerataan mutu pendidikan, (3) mendiskusikan permasalahan yang dihadapi dan dialami oleh guru dalam melaksanakan tugas sehari-hari dan mencari solusi alternatif pemecahannya sesuai dengan karakteristik mata pelajaran masingmasing, guru, kondisi sekolah, dan lingkungannya, (4) membantu guru memperoleh informasi teknis edukatif yang berkaitan dengan kegiatan ilmu pengetahuan dan teknologi, kegiatan kurikulum, metodologi, dan sistem pengujian yang sesuai dengan mata pelajaran yang bersangkutan, dan (5) saling berbagi informasi dan pengalaman dari hasil lokakarya, simposium, seminar, diklat, classroom action research, referensi, dan lain-lain kegiatan profesional yang dibahas bersama-sama. Keenam, mampu menjabarkan dan merumuskan agenda reformasi sekolah (school reform), khususnya focus classroom reform, sehingga berproses pada reorientasi pembelajaran yang efektif.

Kendala kegiatan MGMP yang selama ini dihadapi adalah kurang aktifnya anggota dan kegiatan yang masih monoton sehingga kurang dirasakan manfaatnya oleh guru. Hal ini dapat terjadi karena agenda yang dibahas bukan masalah - masalah aktual yang dibutuhkan oleh guru. Oleh karena itu pengawas selaku supervisor perlu berupaya menggerakkan Musyawarah Guru Mata Pelajaran (MGMP) baik sekolah, kecamatan maupun kabupaten sehingga kegiatan MGMP berjalan dengan baik dan dirasakan manfaatnya oleh guru.

Pengawas memiliki peran yang strategis dalam menggerakkan MGMP sekolah. Dalam melaksanakan perannya pengawas dapat berinisiatif untuk berkoordinasi dengan para guru mata pelajaran. Bahkan pengawas dapat mendorong dengan memberikan topik-topik baru yang sesuai dengan perkembangan yang ada untuk dibahas dalam MGMP. Seiring dengan pemberlakuan kurikulum berbasis kompetensi dan KTSP maka pengawas dapat melaksanakan pembinaan kepada guru melalui forum MGMP 
tentang model-model pembelajaran dan cara penerapannya dalam kegiatan pembelajaran agar meningkat. Salah satu model pembelajaran modern yang perlu diperkenalkan kepada guru ialah PAKEM. Dalam kegiatan ini pengawas memfasilitasi peserta untuk meningkatkan pemahaman, menyusun perencanaan pembelajaran dan belatih menerapkan PAKEM di kelas.

Ada banyak studi terdahulu yang meneliti tentang berbagai upaya untuk meningkatkan kinerja guru. Dari studi tersebut, peneliti telah mengklasifikasikannya ke dalam tiga bentuk penelitian utama. Pertama, supervisi, monitoring dan evaluasi. Menurut penelitian Dwi Sulisworo, Hartono Putut dan Huda Choirul (2017), Sa'Aban (2018), dan Harianto (2019), supervisi akademik atau tindakan aplikatif supervisi kependidikan atau teknik supervisi berkelompok berbasis diskusi dapat meningkatkan kemampuan atau kompetensi guru dalam membuat media pembelajaran dan menyusun Rencana Pelaksanaan Pembelajaran (RPP). Selain itu, Imai Imran (2018) melaporkan bahwa monitoring dan evaluasi dapat meningkatkan penyusunan RPP guru pada sekolah penelitiannya.

Kedua, pelatihan. Hawariyun (2018) tentang 'Pelatihan Mikro teaching' mengungkapkan bahwa profesionalisme guru dalam kepemimpinan pembelajaran yang efektif mengalami peningkatan melalui kegiatan pendamping (mentoring); on the Job Training atau 'Penelitian Tindakan Sekolah (PTS)'. Kegiatan seperti ini dapat meningkatkan kemampuan guru dalam membuat silabus dan RPP, pengelolaan kelas dan penilaian proses serta mengefekifkan pembelajaran.

Dan ketiga, pendampingan. Menurut penelitian Gustirizal (2020), kegiatan pendampingan berbasis bimbingan individu dapat meningkatkan kemampuan guru dalam merancang, menentukan dan menggunakan media pembelajaran.

\section{METODE PENELITIAN}

Penelitian ini menggunakan desain Penelitian Tindakan Kelas (PTK) atau Classroom Action Research (CAR). Suharsimi Arikunto, dkk
(2006: 102) mengatakan bahwa PTK merupakan bentuk penelitian reflektif yang dilakukan oleh pendidik sendiri terhadap kurikulum dan pengembangan sekolah untuk meningkatkan prestasi belakar, mengembangkan keahlian mengajar, dan sebagainya.

Pandangan di atas mengingatkan guru bahwa PTK adalah sebuah upaya untuk mencermati kegiatan belajar anak didik dengan memberikan sebuah tindakan (treatment) yang sengaja dimunculkan. Karena itu, ada empat unsur inti dari pelaksanaan PTK, yaitu: perencanaan (planning), pelaksanaan/tindakan (acting), pengamatan (observing), dan refleksi (reflecting).

Untuk memperoleh data lapangan, penelitian ini telah dilakukan selama tiga bulan, dari Agustus sampai Oktober tahun 2019 dan menggunakan dua siklus. Setiap siklus terdiri dari empat tahapan yaitu perencanaan, pelaksanaan, observasi dan refleksi. Setiap pelaksanaan observasi pada setiap siklus, diadakan kolaborasi dengan kepala sekolah dan setiap akhir siklus diadakan pertemuan dengan kepala sekolah untuk membahas kelemahan pada siklus yang baru selesai dilaksanakan dan merencanakan siklus berikutnya.

Subyek dari penelitian tindakan sekolah ini adalah semua guru mata pelajaran di SMA Negeri 1 Tasifeto Barat. Sejumlah 34 guru mata pelajaran yang terlibat langsung dalam pelaksanaan pembelajaran. Sedangkan obyek penelitian ini adalah pembinaan secara rutin kepada guru-guru mata pelajaran inti baik secara individu maupun kelompok serta secara klasikal.

SMA Negeri 1 Tasfeto Barat dipilih sebagai lokasi penelitian karena sekolah tersebut merupakan salah satu sekolah binaan peneliti, sehingga memudahkan dalam pelaksanaan penelitian.

\section{HASIL DAN PEMBAHASAN}

\section{Hasil}

Seperti telah diuraikan pada Metode Penelitian, penelitian ini menggunakan desain Penelitian Tindakan Kelas (PTK) atau Classroom Action Research (CAR), yang melibatkan empat unsur, yaitu: perencanaan (planning), pelaksanaan/tindakan (acting), pengamatan 
(observing), dan refleksi (reflecting). Untuk melakukan keempat tahap tersebut, peneliti telah berada di lapangan selama tiga bulan, yaitu dari Agustus sampai Oktober tahun 2019.

Keempat tahapan dalam pelaksanaan PTK dibagi ke dalam dua siklus utama yaitu siklus I dan siklus II. Sebelum melaksanakan kedua siklus tersebut, peneliti melakukan observasi di sekolah dan melakukan wawancara dengan kepala sekolah dan guru pada bulan Agustus 2019. Tujuannya ialah agar peneliti dapat mengetahui keadaan guru, interaksi antarkepala sekolah dan guru, dan motivasi mereka untuk mengikuti penelitian ini.

Pada bulan September 2019, peneliti melakukan pembelajaran siklus I, sedangkan pada bulan Oktober 2019, peneliti menerapkan siklus II. Hasil dari penelitian ini akan disampaikan pada tabel-tabel dan uraian berikut.

\section{a. Hasil Penelitian Kondisi Awal}

Berdasarkan pelaksanaann observasi terhadap dokumen administrasi guru tentang penyusunan RPP yang dibuat oleh 34 guru mata pelajaran pada SMA Negeri 1 Tasifeto Barat diperoleh hasil rata-rata $43.63 \%$. Untuk mengetahui hasil lengkap dari penelitian terhadap kondisi awal guru, dapat dilihat pada Tabel $1 \mathrm{di}$ bawah ini.

Tabel 1. Hasil Observasi Dokumen RPP Pra Siklus

\begin{tabular}{|c|c|c|c|c|}
\hline No & Komponen RPP & $\begin{array}{l}\text { Jumlah Guru } \\
\text { yang Mampu } \\
\text { Merumuskan }\end{array}$ & $\begin{array}{l}\text { Persenta } \\
\text { se }\end{array}$ & $\begin{array}{l}\text { Tingkat } \\
\text { Kemampu } \\
\text { an }\end{array}$ \\
\hline 1 & $\begin{array}{l}\text { Merumuskan tujuan } \\
\text { pembelajaran }\end{array}$ & 14 orang & $41.18 \%$ & Kurang \\
\hline 2 & $\begin{array}{l}\text { Mengembangkan dan } \\
\text { mengorganisiasikan materi } \\
\text { media pembelajaran dan } \\
\text { sumber belajar }\end{array}$ & 10 orang & $29.41 \%$ & Kurang \\
\hline 3 & $\begin{array}{l}\text { Merencanakan skenario } \\
\text { kegiatan pembelajaran }\end{array}$ & 12 orang & $35.29 \%$ & Kurang \\
\hline 4 & $\begin{array}{l}\text { Merencanakan prosedur } \\
\text { jenis dan menyiapkan alat } \\
\text { penilaian }\end{array}$ & 13 orang & $38.24 \%$ & Kurang \\
\hline 5 & $\begin{array}{l}\text { Merancang pengelolaan } \\
\text { kelas }\end{array}$ & 18 orang & $52.94 \%$ & Kurang \\
\hline \multirow[t]{2}{*}{6} & $\begin{array}{l}\text { Tampilan dokumen } \\
\text { pembelajaran }\end{array}$ & 22 orang & $64.71 \%$ & Cukup \\
\hline & Rata-rata & & $43.63 \%$ & Kurang \\
\hline
\end{tabular}

\section{b. Siklus I}

\section{1) Perencanaan}

Berdasarkan data awal diketahui bahwa RPP yang disusun oleh guru-guru di SMAN 1 Tasifeto Barat, masih belum lengkap dan berorientasi pada kegiatan pembelajaran yang berpusat pada guru. Selain itu, dalam RPP belum ada kegiatan yang mengaktifkan siswa dalam kegiatan pembelajaran. Hal ini disebabkan oleh beberapa faktor antara lain pemahaman guru terhadap fungsi RPP masih kurang, pengetahuan guru untuk menyusun RPP yang menekankan pembelajaran PAKEM masih kurang, dan belum ada forum khusus yang memberi kesempatan kepada guru untuk menyusun RPP dengan baik.

Berdasarkan hal ini maka disusun rencana untuk meningkatkan pemahaman guru terhadap 
fungsi RPP dan kegiatan MGMP sekolah. Langkah-langkah perencanaan yang dilakukan adalah: (1) berkoordinasi dengan kepala sekolah agar kepala sekolah membentuk MGMP sekolah dengan menunjuk guru-guru senior sebagai koordinator mata pelajaran dengan surat keputusan kepala sekolah, (2) meminta kepala sekolah untuk menugaskan wakil kepala sekolah bidang kurikulum dalam menyusun jadwal pelajaran agar memberi kesempatan satu hari dalam satu minggu guru mapel sejenis dapat melaksanakan pertemuan rutin/MGMP sekolah, (3) berkoordinasi dengan guru untuk mengadakan pertemuan membahas RPP dengan nara sumber pengawas, dan (4) melaksanakan MGMP untuk menyusun RPP dengan yang menekankan pada pembelajaran kooperatif.

\section{2) Pelaksanakan}

Berdasarkan perencanaan yang dibuat maka dilakukan pelaksanaan sesuai dengan rencana yaitu: (1) koordinasi dengan kepala sekolah membicarakan pembentukan MGMP sekolah dengan menunjuk koordinator mata pelajaran, (2) penyusunan jadwal pelajaran dan MGMP sekolah oleh waksek kurikulum, dan (3) melaksanakan pertemuan MGMP sekolah. Dalam pertemuan ini guru diminta mengumpulkan contoh RPP yang selama ini sudah dibuat, mendiskusikan penyusunan RPP yang menekankan pada pembelajaran aktif, kreatif, efektif.dan menyenangkan.

\section{3) Observasi}

Observasi dan pengumpulan data pada siklus I menghasilkan data sebagai berikut: (1) Kepala SMAN 1 Tasifeto Barat telah menindaklanjuti hasil koordinasi dengan membentuk MGMP sekolah dengan menunjuk koordinator MGMP, (2) Wakil kepala sekolah bidang kurikulum menyusun pembagian tugas mengajar dan menjadwalkan waktu khusus untuk kegiatan MGMP, dan (3) penilaian terhadap kemampuan guru menyusun RPP menggunakan Instrumen Penilaian Kinerja Guru (IPKG) terhadap RPP yang dibuat guru adalah sebagai berikut:

\section{a) Sebelum MGMP sekolah dilaksanakan}

Ada enam kegiatan yang diobservasi sebelum MGMP sekolah dilaksanakan, yaitu kemampuan merumuskan tujuan pembelajaran, mengembangkan dan mengoordinasikan materi, media pembelajaran dan sumber belajar, merencanakan skenario pembelajaran, merancang pengelolaan kelas, merencanakan prosedur, jenis dan menyiapkan alat penilaian.

Seperti diungkapkan pada Tabel 1 di atas, melalui observasi, peneliti menemukan bahwa tampilan dokumen 64.71\%, kemampuan merumuskan tujuan pembelajaran $41.18 \%$, kemampuan mengembangkan dan mengoordinasikan materi, media pembelajaran dan sumber belajar $29.41 \%$, kemampuan merencanakan skenario pembelajaran $35.29 \%$, kemampuan merancang pengelolaan kelas $52.94 \%$, kemampuan merencanakan prosedur, jenis dan menyiapkan alat penilaian $38.24 \%$, dan tampilan dokumen $64.71 \%$.

Dari data pada Tabel 1 terlihat jelas bahwa kemampuan guru untuk merencanakan skenario pembelajaran dan kemampuan untuk merencanakan prosedur, jenis dan menyiapkan alat penilaian masing-masing hanya mecapai $35.29 \%$ dan $38.24 \%$. Di sisi lain, guru juga kurang memiliki kemampuan yang cukup baik untuk merencanakan pembelajarannya. Kemampuan mereka tidak mencapai $65 \%$. Kenyataan ini membutuhkan sentuhan lain agar kemampuan guru benar-benar ditingkatkan sehingga pembelajarannya bisa membuat siswa belajar.

\section{b) Sesudah MGMP pada siklus}

Hasil observasi terhadap dokumen administrasi guru tentang penyusunan RPP yang dibuat oleh 34 guru mata pelajaran pada SMA Negeri 1 Tasifeto Barat menunjukkan bahwa ratarata kemampuan guru masih $43,63 \%$. Kenyataan ini tentu saja sungguh-sungguh menyedihkan. Karena itu, peneliti melakukan observasi sesudah MGMP pada siklus I. Observasi tersebut difokuskan pada enam kemampuan yaitu kemampuan merumuskan tujuan pembelajaran, mengembangkan dan mengorganisasikan materi, media pembelajaran dan sumber belajar, merencanakan skenario pembelajaran, merancang pengelolaan kelas, merencanakan prosedur, jenis dan menyiapkan alat penilaian, dan tampilan dokumen. 
Hasil observasi sesudah MGMP menunjukkan bahwa kemampuan merumuskan tujuan pembelajaran $55.88 \%$, kemampuan mengembangkan dan mengorganisasikan materi, media pembelajaran dan sumber belajar $44.12 \%$, kemampuan merencanakanscenario pembelajaran $50.00 \%$, kemampuan merancang pengelolaan kelas $67.65 \%$, kemampuan merencanakan prosedur, jenis dan menyiapkan alat penilaian $52.94 \%$, dan tampilan dokumen $79.41 \%$.

Data di atas dan yang tertuang pada Tabel 2 di bawah ini, menunjukkan bahwa kemampuan guru mengalami sedikit peningkatan pada beberapa aspek. Ini disebabkan oleh adanya perubahan pola pikir mereka yang meyakini bahwa pelatihan dan/atau pendampingan sangat penting bagi pengembangan kemampuan mereka.

Tabel 2. Hasil Observasi Dokumen RPP Siklus I

\begin{tabular}{|c|c|c|c|c|}
\hline No & Komponen RPP & $\begin{array}{l}\text { Jumlah Guru } \\
\text { yang Mampu } \\
\text { Merumuskan }\end{array}$ & Persentase & $\begin{array}{l}\text { Tingkat } \\
\text { Kemam } \\
\text { puan }\end{array}$ \\
\hline 1 & $\begin{array}{l}\text { Merumuskan tujuan } \\
\text { pembelajaran }\end{array}$ & 19 orang & $55.88 \%$ & Kurang \\
\hline 2 & $\begin{array}{l}\text { Mengembangkan dan } \\
\text { mengorganisiasikan materi } \\
\text { media pembelajaran dan } \\
\text { sumber belajar }\end{array}$ & 15 orang & $44.12 \%$ & Kurang \\
\hline 3 & $\begin{array}{l}\text { Merencanakan scenario } \\
\text { kegiatan pembelajaran }\end{array}$ & 17 orang & $50.00 \%$ & Kurang \\
\hline 4 & $\begin{array}{l}\text { Merencanakan prosedur } \\
\text { jenis dan menyiapkan alat } \\
\text { penilaian }\end{array}$ & 18 orang & $54.94 \%$ & Kurang \\
\hline 5 & $\begin{array}{l}\text { Merancang pengelolaan } \\
\text { kelas }\end{array}$ & 23 orang & $67.65 \%$ & Cukup \\
\hline \multirow[t]{2}{*}{6} & $\begin{array}{ll}\text { Tampilan } & \text { dokumen } \\
\text { pembelajaran } & \end{array}$ & 27 orang & $79.41 \%$ & Baik \\
\hline & Rata-rata & & $58.67 \%$ & Kurang \\
\hline
\end{tabular}

4) Refleksi

Berdasarkan data hasil observasi tersebut dapat disimpulkan bahwa pelaksanaan MGMP sekolah mendapatkan dukungan penuh dari pimpinan sekolah. Hal itu ditandai dengan upaya kepala sekolah dan wakil kepala sekolah untuk mengatur secara khusus kegiatan tersebut dan memfasilitasi para guru untuk tidak mengajar pada hari MGMP yang telah ditentukan. Juga, semua guru memiliki motivasi tinggi untuk mengikuti MGMP. Ini menandakan bahwa kualitas kemampuan pembelajaran mereka mau diubah dan ditingkatkan.
Jika diperbandingkan hasil observasi terhadap rencana pembelajaran yang dibuat oleh guru sebelum kegiatan MGMP dan sesudah MGMP dapat disampaikan sebagai berikut: (1) kemampuan merumuskan tujuan pembelajaran meningkat dari $41.18 \%$ menjadi $55.88 \%$, (2) kemampuan mengembangkan dan mengorganisasikan materi, media dan sumber belajar meningkat dari $29.41 \%$ menjadi $44.12 \%$, (3) kemampuan merencanalan skenario pembelajaran meningkat dari $35.29 \%$ menjadi $50.00 \%$, (4) kemampuan merancang pengelolaan kelas meningkat dari $52.94 \%$ menjadi $67.65 \%$, (5) kemampuan merencanakan prosedur, jenis dan 
menyiapkan alat penilaian meningkat dari $38.24 \%$ menjadi $52.94 \%$, dan (6) tampilan dokumen meningkat dari $64.71 \%$ menjadi $79.41 \%$.

Dari data tersebut dapat disimpulkan bahwa secara umum MGMP sekolah berhasil meningkatkan kemampuan guru dalam menyusun RPP. Kemampuan guru yang peningkatannya paling rendah adalah kemampuan merumuskan tujuan pembelajaran. Pada umumnya guru lemah dalam merumuskan tujuan yang mengandung kecakapan hidup.

Beberapa kemampuan dalam menyusun RPP yang masih mungkin untuk ditingkatkan adalah: (1) kemampuan merumuskan tujuan pembelajaran, (2) kemampuan mengembangkan dan mengorganisasikan materi, media dan sumber belajar, (3) kemampuan merencanakan scenario pembelajaran, (4) kemampuan merencanakan prosedur, jenis dan menyiapkan alat penilaian.

\section{b. Siklus II \\ 1) Perencanaan}

Berdasarkan refleksi pada siklus I direncanakan tindakan untuk siklus II. Adapun tindakan yang direncanakan adalah: (1) memberikan umpan balik hasil penilaian pada pra siklus dan siklus I, (2) mendiskusikan hasil penilaian dengan guru, (3) meminta guru untuk membuat RPP, (4) meminta guru memberikan penilaian/kesan tentang pelaksanaan MGMP sekolah, dan (5) menilai RPP yang disusun oleh guru.

\section{2) Tindakan}

Berdasarkan perencanaan yang dibuat pada siklus II dilaksanakan tindakan sebagai berikut: (1) memberikan umpan balik hasil penilaian kepada guru dan menyampaikan kepada guru kriteria yang digunakan sebagai dasar melakukan penilaian RPP, (2) mendiskusikan hasil penilaian bersama guru terutama cara merumuskan komponen-komponen dalam RPP yang masih kurang, (3) memberikan kesempatan guru untuk menyusun RPP, (4) meminta guru untuk memberikan kesan tentang pelaksanaan MGMP sekolah, dan (5) melakukan penilaian RPP yang dibuat oleh guru.

\section{3) Observasi}

Observasi pada siklus II dilaksanakan selama kegiatan MGMP berlangsung untuk mengamati pelaksanaan MGMP, menilai RPP yang dihasilkan, dan merangkum kesan - kesan guru terhadap pelaksanaan MGMP. Pada pertemuan MGMP yang dihadiri oleh semua guru (34 guru) disampaikan umpan balik banyak muncul adalah cara merumuskan tujuan pembelajaran yang mengandung kecakapan hidup, dan penilaian.

Diskusi antar peserta banyak menyoroti rumusan tujuan yang telah dirumuskan masingmasing guru. Namun demikian masih terdapat penafsiran yang belum seragam antar guru dalam menilai sebuah rumusan mengandung kecakapan hidup atau tidak.

Sementara itu peserta MGMP yang menyampaikan kesan-kesannya bahwa MGMP sekolah yang diadakan: (1) bermanfaat, (2) menambah wawasan, (3) dapat digunakan untuk sharing mengatasi kesulitan, (4) mempermudah mengerjakan tugas, (5) membantu menyelesaikan tugas guru, (6) menambah ilmu, (7) bisa memperbaiki pengembangan pengajaran, dan (8) dapat memperbaiki metode mengajar.

Persentase hasil observasi dokumen RPP yang disusun guru adalah sebagai berikut: (1) kemampuan merumuskan tujuan pembelajaran $64.71 \%$, (2) kemampuan mengembangkan dan mengorganisasikan materi, media pembelajaran dan sumber belajar $52.94 \%$, (3) kemampuan merencanakan scenario pembelajaran $58.82 \%$, (4) Kemampuan merancang pengelolaan kelas $67.65 \%$, (5) kemampuan merencanakan prosedur, jenis dan menyiapkan alat penilaian $50.00 \%$, dan (6) tampilan dokumen $88.24 \%$, seperti tertuang pada Tabel 3 berikut ini. 
Tabel 3. Hasil Observasi Dokumen RPP Siklus II

\begin{tabular}{|c|c|c|c|c|}
\hline No & Komponen RPP & $\begin{array}{c}\text { Jumlah Guru yang } \\
\text { Mampu } \\
\text { Merumuskan }\end{array}$ & Persentase & $\begin{array}{l}\text { Tingkat } \\
\text { Kemampuan }\end{array}$ \\
\hline 1 & Merumuskan tujuan pembelajaran & 22 orang & $64.71 \%$ & Cukup \\
\hline 2 & $\begin{array}{l}\text { Mengembangkan dan } \\
\text { mengorganisiasikan materi media } \\
\text { pembelajaran dan sumber belajar }\end{array}$ & 18 orang & $52.94 \%$ & Kurang \\
\hline 3 & $\begin{array}{l}\text { Merencanakan scenario kegiatan } \\
\text { pembelajaran }\end{array}$ & 20 orang & $58.82 \%$ & Kurang \\
\hline 4 & $\begin{array}{l}\text { Merencanakan prosedur jenis dan } \\
\text { menyiapkan alat penilaian }\end{array}$ & 17 orang & $50.00 \%$ & Kurang \\
\hline 5 & Merancang pengelolaan kelas & 23 orang & $67.65 \%$ & Cukup \\
\hline \multirow[t]{2}{*}{6} & Tampilan dokumen pembelajaran & 30 orang & $88.24 \%$ & Sangat Baik \\
\hline & Rata-rata & & $63.73 \%$ & Cukup \\
\hline
\end{tabular}

\section{4) Refleksi}

Kemampuan guru dalam menyusun RPP secara umum meningkat hal ini didasarkan pada perbandingan prosentase kemampuan guru menyusun RPP siklus II yang rata - rata lebih besar dibandingkan nilai prosentase RPP pada siklus I.

Penilaian terhadap kemampuan guru merumuskan tujuan pembelajaran meningkat dari $55.88 \%$ pada siklus I, menjadi $64.71 \%$ pada siklus II. Peningkatan ini disebabkan oleh meningkatnya kemampuan merumuskan kompetensi dasar/indikator hasil belajar.

Kemampuan mengembangkan dan mengorganisasi materi, media pembelajaran dan sumber belajar meningkat dari $44.12 \%$ pada siklus I, menjadi 52.94\% pada siklus II. Hal ini karena adanya peningkatan nilai pada sub komponen menentukan dan mengembangkan media pembelajaran dan memilih sumber belajar.

Kemampuan merancang scenario pembelajaran meningkat dari $50.00 \%$ pada siklus I menjadi $58.82 \%$. Peningkatan terjadi karena adanya peningkatan nilai pada sub komponen menentukan alokasi waktu pembelajaran. Pada siklus I pada umumnya guru belum mencantumkan rincian waktu secara proporsional sedangkan pada siklus II sudah dirinci secara proporsional.

Kemampuan merancang pengelolaan kelas masih belum ada peningkatan persentase meskipun karena pada sub komponen menentukan cara-cara mengorganisasikan siswa agar berpartisipasi dalam kegiatan pembelajaran sudah maksimal.

Kemampuan merencanakan dan menyiapkan alat penilaian ternyata terjadi penurunan karena ada guru yang pada siklus I membuat secara lengkap jenis penilaian, teknik penilaian dan sinstrument yang dilengkapi dengan kunci jawaban dan penskoran tetapi pada siklus II tidak membuat. Hal ini karena yang bersangkutan pada saat siklus II berlangsung sedang melaksanakan pernikahan.

Berdasarkan data penilaian terhadap rencana pelaksanaan pembelajaran terjadi peningkatan rata-rata prosentase baik pada siklus I maupun siklus II. Jika sebelum dilakukan, tindakan rata-rata prosentase adalah $43.63 \%$ setelah dilakukan tindakan siklus I, rata-rata prosentase meningkat menjadi $58.67 \%$ atau meningkat $15.04 \%$ dari sebelum tindakan dilakukan dan siklus II rata-rata prosentase $63.73 \%$ atau meningkat $5.06 \%$ dari siklus I.

Peningkatan terjadi pada hampir semua komponen dalam penyusunan RPP. Tetapi komponen yang peningkatannya nilainya paling tinggi adalah pada komponen tampilan dokumen pembelajaran dan merancang pengelolaan kelas. Pada komponen menentukan skenario pembelajaran terjadi peningkatan prosentase pada 
siklus I sebesar $14.71 \%$ dari sebelum tindakan dilakukan dan pada siklus II terjadi peningkatan sebesar $8.82 \%$ dari siklus I. Pada komponen pengelolaan kelas terjadi peningkatan prosentase pada siklus I sebesar $14.71 \%$ dari sebelum tindakan, namun pada siklus II tidak terjadi peningkatan lagi.

\section{Pembahasan}

Pada bagian ini, penulis akan berusaha membandingkan hasil penelitian sekarang dengan hasil-hasil studi sebelumnya, yang berhubungan dengan penerapan PAKEM dalam pembelajaran, supervisi, monitoring dan evaluasi, dan pelatihan yang dilakukan untuk meningkatkan kompetensi, keahlian dan kualitas kinerja guru dalam mengembangkan pembelajarannya.

Beberapa studi terdahulu tentang penggunaan Model PAKEM dalam pembelajaran telah mengungkapkan keefektivitasannya. Misalnya, Dede Rohaniawati (2016), I Iesti Surya Ningsih, dan Yudi Darma, dan Yadi Ardiawan (2018) menemukan bahwa pembelajaran siswa dengan menggunakan pendekatan atau model PAKEM dapat meningkatkan interaksi dan komunikasi antara guru dan siswa. Hal yang sama juga diakui oleh S. A. Suharman, Pariabti Palloan dan Eko Hadi Sujiono (2011). Dengan penggunakan rumus persentase dan "r" Product Moment dan pengujian statistik inferensial, mereka menemukan korelasi dan pengaruh penggunaan PAKEM dalam pembelajaran siswa.

Penelitian yang tidak kalah menariknya ialah yang dilakukan Harlina (2017) dan Yuliarni (2017), Nursina (2019), Suhelpi (2020), Zulherlita (2019) "In House Training (IHT)", Was was (2017) "workshop", Elmawati (2017), Harisman (2017), dan Doni Chandra (2018) "On the Job Training". Mereka menyatakan bahwa kegiatan tersebut dapat meningkatkan kemampuan guru dalam membuat silabus dan RPP.

Selain itu, ada banyak studi terdahulu yang meneliti tentang berbagai upaya untuk meningkatkan kinerja guru. Pertama, supervisi, monitoring dan evaluasi. Ditemukan bahwa supervisi akademik atau tindakan aplikatif supervisi kependidikan atau teknik supervisi berkelompok berbasis diskusi dapat meningkatkan kemampuan atau kompetensi guru dalam membuat media pembelajaran dan menyusun RPP (Dwi Sulisworo, Hartono Putut dan Huda Choirul, 2017; Sa'Aban, 2018; Harianto, 2019; dan Imai Imran, 2018).

Bidang lain yang diteliti ialah pelatihan, seperti micro teaching, on/in the job training atau Penelitian Tindakan Sekolah (PTS) juga turut meningkatkan profesionalisme guru dalam kepemimpinan pembelajaran yang efektif, misalnya pembuatan silabus dan RPP, pengelolaan kelas dan penilaian proses (Hawariyun, 2018). Dan yang penting ialah pendampingan. Kegiatan pendampingan yang berbasis bimbingan individu ternyata mampu meningkatkan kemampuan guru untuk merancang, menentukan dan menggunakan media pembelajaran (Gustirizal, 2020).

Dari uraian mengenai hasil-hasil penelitian sebelumnya dan dibandingkan dengan hasil penelitian sekarang, maka tidak ditemukan perbedaan yang signifikan. Misalnya, dua dari banyak studi tentang PAKEM dan hal lainnya dilakukan oleh Yuslina (2018) dan Gustirizal (2020). Keduanya menemukan bahwa PAKEM mampu mengubah penampilan guru dalam mengelola pembelajarannya, yang membuat dan mendorong siswa dengan semangat yang tinggi mengikuti pembelajaran.

Namun, hasil penelitian terdahulu dengan sekarang mengalami perbedaan pada beberapa aspek. Pertama, peningkatan terjadi pada hampir semua komponen dalam penyusunan RPP. Komponen yang peningkatan nilainya paling tinggi adalah pada komponen tampilan dokumen pembelajaran dan merancang pengelolaan kelas. Pada komponen menentukan skenario pembelajaran terjadi peningkatan persentase pada siklus I sebesar $14.71 \%$ dari sebelum tindakan dilakukan dan pada siklus II menjadi $8.82 \%$ dari siklus I. Pada komponen pengelolaan kelas terjadi peningkatan prosentase pada siklus I sebesar $14.71 \%$ dari sebelum tindakan, namun pada siklus II tidak terjadi peningkatan lagi.

Kedua, peningkatan persentasi kesuksesan penerapan pendekatan PAKEM dalam penelitian ini membuktikan bahwa sebelum dilakukan penelitian ini, para guru SMAN 1 Tasifeto Barat masih lemah dalam menyusun rencana 
pembelajaran. Kelemahan-kelemahannya antara lain: Pertama, pada penentuan kegiatan pembelajaran masih kurang menggunakan metode yang bervariasi, kurang melibatkan siswa secara optimal dan kurang memberikan peluang terjadinya proses inquiry; Kedua, pada penyusunan langkah-langkah pembelajaran belum mencantumkan rencana kegiatan terstruktur dan kegiatan mandiri siswa; ketiga, pada penentuan cara-cara memotivasi siswa kurang memberikan kegiatan yang mudah dan menantang diikuti oleh siswa; dan keempat, pertanyaan yang dipersiapkan oleh guru masih banyak yang bersifat ingatan dan penerapan belum terdapat pertanyaan analisis dan sintesis.

Demikian juga dalam pengelolaan kelas, masih banyak guru peserta MGMP sekolah di SMAN 1 Tasifeto Barat lemah pada pengorganisasian siswa agar berpartisipasi dalam kegiatan pembelajaran. Dari keseluruhan guru, RPP yang dibuat kurang menampakkan pengorganisasian siswa dan dalam memberikan kesempatan kepada siswa dalam mendiskusikan tugas atau kegiatan pembelajaran.

Setelah dilakukan tindakan pembinaaan oleh pengawas dalam kegiatan MGMP sekolah, ternyata mereka mampu menunjukkan perubahan dalam penyusunan RPP. Perubahan-perubahan itu adalah pertama, pada komponen RPP, mereka mampu menyusun skenario kegiatan pembelajaran pada sub komponen menentukan jenis kegiatan pembeljaran sudah mencantumkan metode yang bervariai, memungkinkan keterlibatan siswa, dan sudah memberikan peluang terjadinya proses inquiry. Kedua, pada penyusunan langkah-langkah pembelajaran sudah disusun dengan mencantumkan langkah pembukaan, inti dan penutup secara rinci disertai dengan rencana kegiatan terstruktur dan mandiri. Ketiga, pada penentukan cara-cara memotivasi siswa sudah mencantumkan bahan pengait, mempersiapkan media yang menarik, menetapkan kegiatan yang mudah dan menantang siswa serta melibatkan siswa dalam kegiatan. Keempat, pertanyaanpertanyaan yang disiapkan tidak hanya pertanyaan yang bersifat ingatan saja tetapi juga penerapan dan beberapa pertanyaan analisis. Dan terakhir, pada perancangan pengelolaan kelas juga sudah dipersiapkan pembelajaran yang sesuai dengan lingkungan, sudah mengorganisasikan siswa secara berkelompok atau individu dengan tugas dan alur kerja yang jelas memberikan kesempatan siswa untuk melaksanakan pembelajaran yang aktif, kreatif, efektif, dan menyenangkan.

Sekalipun telah menunjukkan hasil positif, penelitian ini mengalami tiga kelemahan utama. Pertama, peneliti memiliki keterbatasan akses untuk menjangkau semua guru sebagai subyek penelitian. Itu terjadi karena peneliti memiliki keterbatasan dana dan waktu.

Kedua, substansi dari penelitian ini hanya terfokus RPP yang sudah disiapkan guru. Ini terjadi karena peneliti yakin, semua guru memiliki kewajiban untuk membuat perangkat pembelajarannya, seperti LKS, RPP dan materi pembelajaran. Kenyataann menunjukkan bahwa masih ada guru membuat perangkat pembelajaran yang tidak sesuai dengan petunjuk teknis yang disiapkan.

Dan ketiga, peneliti tidak mampu membuat pelatihan MGMP sekolah yang cukup lama dan menghadirkan para ahli untuk menambah wawasan guru. Ini disebabkan oleh keterbatasan dana pada peneliti. Padahal, jika pelatihan MGMP dilakukan secara bertahap dan agak lama, akan terungkap apakah guru aktif mengikuti pelatihan atau tidak peduli pada perubahan kinerjanya dan apakah kualitas persiapan dan pelaksanaan perangkat pembelajarannya benar-benar meningkat.

\section{SIMPULAN DAN REKOMENDASI}

Berdasarkan analisis terhadap temuan penelitian tentang upaya peningkatan kualitas guru dalam melaksanakan pembelajaran menggunakan pembelajaran aktif, kreatif, efektif dan menyenangkan, melalui pembinaan pengawas di MGMP sekolah dapat disimpulkan bahwa para guru memiliki kemampuan awal untuk mengelola kelas atau pembelajaran dengan baik. Kemampuan ini ternyata kurang bisa dikembangkan karena mereka dihadapkan dengan kebijakan sekolah yang kurang mendukung pengembangan ketrampilannya, seperti terbatasnya dana untuk kegiatan MGMP sekolah dan pelatihan lainnya di luar sekolah. 
Selain itu, pengawasan kepala sekolah terhadap pengembangan kinerja guru kurang mampu membangkitkan gairah guru untuk meningkatkan kualitas diri dalam menjalankan tugasnya, seperti tidak pernah memeriksa perangkat pembelajaran guru dan memonitor kehadiran guru di kelas. Jika ada guru yang sering absen, tidak ada tindakan yang diberikan, yang membuat guru rajin ke sekolah.

Karena itu, pengawas sekolah dapat memanfaatkan forum MGMP sekolah sebagai sasaran pembinaan guru untuk meningkatkan kwalitas kegiatan pembelajaran. Selain itu, kepala sekolah perlu mendorong dan memfasilitasi pelaksanaan MGMP sekolah dan kegiatan lain di luar sekolah karena terbukti MGMP sekolah dapat dijadikan sebagai wahana pembinaan kualitas guru. Dan, guru dapat aktif mengikuti kegiatan MGMP sekolah atau kegiatan lain di luar sekolah sebagai salah satu forum yang mampu meningkatkan kualitas pembelajarannya.

\section{DAFTAR PUSTAKA}

Achmad, A. (2004). Pemberdayaan MGMP, Sebuah Keniscayaan. Jurnal Pendidikan, 2(1), 12-20.

Akhyar, Z., D. A. Ruchliyadi dan A. Ansari. (2014). Penerapan Pendekatan Pemelajaran PAKEM dan Kontekstual dalam Mengatasi Kesulitan Belajar Siswa pada Pembelajaran PKn di SMA Muhammadiyah 2 Banjarmasin. Jurnal Pendidikan Kewarganegaraan, 4(8), 594-599.

Arikunto, S., Sukarjono \& Supardi. (2006). Penelitian Tindakan Kelas. Jakarta: Bumi Aksara.

Gustirizal. (2020). Peningkatan Kemampuan Guru dalam Menggunakan Media Pembelajaran melalui Pendampingan Berbasis Bimbingan Individu di SMAN 2 Pasaman. Jurnal Manajemen Pendidikan, 5(1), 1-12.

Harianto, H. (2019). Upaya Peningkatan Kompetensi Pedagogik Guru melalui Supervisi Akademik di MAN 4 Pasaman Barat. Jurnal Manajemen Pendidikan, 4(3), 391-398.
Hawariyun. (2017). Mendirikan Musyawarah Guru Mata Pelajaran (MGMP) Geografi di Kabupaten Pasaman Barat, Sumatera Barat. Jurnal Manajemen Pendidikan, 2(2), 321-326.

Kemmis, S dan R. McTaggart. (1988). The Action Research Planner. Victoria: Deakin University.

Madya, S. (1994). Panduan Penelitian Tindakan Kelas. Yogyakarta: Lemlit IKIP Yogyakarta.

Mulyasa, E. (2004). Menjadi Kepala Sekolah Profesional dalam Konteks Menyukseskan MBS dan KBK. Bandung: PT. Remaja Rosdakarya.

Nasution S. (2000). Berbagai Pendekatan dalam Proses Belajar dan Mengajar. Jakarta: PT. Bumi Aksara.

Ningsih, I. I. S., Y. Darma, \& Y. Ardiawan. (2018). Penerapan Model Pembelajaran PAKEM dengan Menggunakan Bantuan GAMES Miskin pada Materi PLSV Kelas X SMA Negeri 2 Meliau. Jurnal Pendidikan Informatika dan Sains, 7(1), 42-53.

Nurhadi, S. (2003). Pembelajaran Kontekstual (Contextual Teaching and Learning /CTL) dan Penerapannya Dalam KBK. Malang: UM Press.

Rohaniawati, D. (2016). Penerapan Pendekatan PAKEM untuk Meningkatkan Keterampilan Berpikir Mahasiswa dalam Mata Kuliah Pengembangan Kepribadian Guru. Tadris: Jurnal Keguruan dan Ilmu Tarbiyah 1(2), 155 172.

Sa'Aban. (2018). Peningkatan Kompetensi Guru dalam Menyusun Rencana Pelaksanaan Pembelajaran melalui Supervisi Akademik Pengawas Sekolah Binaan Pasaman Barat SMPN 2 Gunung Tuleh. Jurnal Manajemen Pendidikan, 3(1), 8592.

Saptaningrum, E., W. Kusdaryani \& F. Refiane. (2012). Model Pembelajaran Aktif Efektif Menyenangkan melalui Pendekatan Tematik untuk Pembelajaran Sains. Jurnal Penelitian Pembelajaran 
Fisika, 2(1),

34-44.

DOI: 10.26877/jp2f.v2il/April.125.

Sardiman. (2004). Interaksi dan Motivasi Belajar Mengajar. Jakarta: PT. Raja Grafindo Persada.

Somantri, H. (2009). Peningkatan Prestasi Belajar Siswa Melalui Pendekatan PAKEM. Jurnal Administrasi Pendidikan UPI, $I X(1)$.

DOI: https://doi.org/10.17509/jap.v9i1.

Sudjana, N. (2006). STANDAR MUTU PENGAWAS. Jakarta: Depdiknas.

Sudrajat, A. (2008). Tugas Pokok dan Fungsi Pengawas Satuan Pendidikan. Blog Pendidikan AKHMAD SUDRAJAT tentang PENDIDIKAN: https://akhmadsudrajat.wordpress.com/ 2008/04/08/tugas-pokok-fungsi-hakdan-wewenang-pengawassekolahsatuan-pendidikan/

Suharman, S. A., Pariabti Palloan \& Eko Hadi Sujiono. (2011). Penerapan Pendekatan Pakem (Pembelajaran Aktif Kreatif Efektif dan Menyenangkan) untuk Meningkatkan Hasil Belajar Fisika Siswa Kelas X2 SMA Negeri 1 Pangkajene. Jurnal Sains dan Pendidikan Fisika, 7(1), 140-152. DOI 10.35580/jspf.v7i2.952.

Sulisworo, D., H. Putut \& H. Choirul. (2017). Analisis Hasil Supervisi Akademik Guru SMP di Purworejo, Jawa Tengah. Jurnal Manajemen Pendidikan, 2(3), 527-534.

Syafril. (2018). Peningkatan Kualitas Penyusunan RPP melalui Monitoring dan Evaluasi Pelaksanaan Program Sekolah oleh Guru di SMAN 1 Kinali. Jurnal Manajemen Pendidikan, 3(1), 93-102.

Windhiyanti. (2010). Meningkatkan Hasil Belajar IPS tentang Kedudukan dalam Keluarga dengan Pendekatan PAKEM. Jurnal Perspektif Ilmu Pendidikan, 22(XIII), 5865.

Zuriah. (2003). Konsep-Konsep dan Teknik Supervisi Pendidikan Dalam Rangka Pengembangan Sumber Daya Manusia. Jakarta: Rineka Cipta. 